Changing Societies \& Personalities, 2017

Vol. 1, No. 1

http://dx.doi.org/10.15826/csp.2017.1.1.003

Article

\title{
Beyond the Freakonomics of Religious Liberty
}

\author{
Ivan Strenski \\ University of California, Riverside, USA
}

\begin{abstract}
The paper critiques the prevailing liberal market economy models of religious liberty and religious encounter. In place of market models, this paper argues that values inscribed in gift exchange, hospitality, guest/host relations, in many cases, and to varying degrees, provide better alternative values to govern religious interaction than those of the market model. Instead of conceiving religion as commodity for "sale" - adoption, conversion and instead of conceiving missionaries as salespeople for their religions, I propose that the encounter of religions could be better conceived in terms of guest/host, gift giver/gift receiver relations. "Freakonomics", therefore, whether in free market or monopoly form - does not, therefore, write the last page in the story of religious liberty.
\end{abstract}

\section{KEYWORDS}

Armenia, Freakonomics, guest/host, Holy Armenian Apostolic Church, liberty, market values, missionaries, religion.

\section{"Religious Liberty" as Commodity}

In May of 2013, I was invited to lecture in Armenia on religious liberty. Instead of teaching, I was "taken to school" about how West and East clashed over religious liberty. For Western governmental, religious and humanitarian groups, the values governing religious liberty or freedom were analogous to the values governing economic markets. The religious "marketplace" should be free and open to all competitors. Religious people should be free to make a "rational choice" of a religion. They should not be regulated in 
making their fundamental religious decisions. Individual conscience should be their guide. For the East - the Holy Armenia Apostolic Church (HAAC, hereafter), economic values likewise governed the way it should be with religion. In their case, however, the religious "marketplace" should be tightly regulated, indeed made subject to their monopoly. What mattered most were the historic collective values of national identity and history. Such values put the HAAC firmly in control of religious transactions in the religious marketplace in Armenia. I want first of all to point out that both West and East assume a market model of religion. They differ only as to the degree of freedom in that market. Both, in effect, would agree that the dominant values of the religious realm conform to what Steven D. Levitt and Stephen J. Dubner have written in their book, Freakonomics. (Levitt \& Dubner 2009). The discourse on international religious liberty is, thus, thought to play (and ought to play) by Levitt and Dubner's "hidden" rules of economic exchange.

But, should it? I shall argue that the standard "Freakonomic" model may encounter intractable obstacles to successful application. The market model need not govern religious encounter and exchange any more than it needs to encompass all our other kinds of exchange. All the more applies with equal force to monopolists, like the HAAC. The values inherent in what we call "the economy," the market, whether free or regulated, is a relatively late, though doubtless often overwhelming. Religious folk should, for instance, choose the "best" religion - one that rationally maximized their religious "profit," such as their opportunity for salvation. But, if we follow Karl Polanyi's powerful sweeping arguments in his The Great Transformation, then we would recognize that profitmaximizing rationality was not always the dominant value in systems of human exchange. (Polanyi 1944) Without reciting Polanyi's entire arguments, we can glean from him the notion of the historicity of our values about exchange. While it is natural for us, who are dominated by the values of economic society, to regard our world with the market foremost in mind, other peoples, past and present, need not do so as well, or at least in as thoroughgoing a fashion as we do.

With Polanyi in mind, I want to argue, instead, that it might be better to think about religious liberty on models embodying other kinds 
of values than those dominating our thinking as citizens of economic society. I suggest that the values inscribed in gift exchange, of hospitality - of guest/host, not economic exchange - provide alternative values governing religious interaction to those of the market model. "Freakonomics" - whether in free market or monopoly form - does not write the last page in the story of religious liberty.

\section{The Market Values of the Venice Commission Report in Armenia}

To set my thesis in a concrete context, I would point out how prominent official agencies in the West, such as the European Union's Venice Commission conceive the engagement of religions in the public square. For them, not surprisingly, a dominant liberal, rational choice indeed, "Freakonomic" - model rules. Market values inform official thinking about how religions should get on in a liberal democratic nation-state. Religions thus "sell" their wares (proselytize), "buy into" or "buy out" of a condition of membership (are converted or depart), "win over customers" (gain converts), satisfy their "consumers" (believers, adherents), and so on. In its report of 14-15 October 2011, the Venice Commission concluded its review of proposed revisions to the Armenian constitution and the role of the HAAC. These revisions granted to the HAAC a "list of exclusive missions" (in Freakonomic terms, "franchises") such as "freely preaching and disseminating its religion'; 'building new churches'; contributing to the spiritual education of the Armenian people" and so on. Critically, in Paragraph 96, the Venice Commission report noted, "that other religious associations will not be allowed to engage in such activities" (in Freakonomic terms, establish a cartel or monopoly). In effect, the HAAC sought to monopolize the field of religious choice in Armenia, to "corner the market," so to speak. "Such a restriction," the report goes on, "would violate international standards on freedom of religion or belief and on the prohibition of non-discrimination" (Flanagan, et al. 2011) ${ }^{1}$ - because it violated the value of the autonomy of the "market."

\footnotetext{
${ }^{1}$ Much the same principles have been enunciated in the US Congress' "International Religious Freedom Act of 1998" (H. R. 2431), which, in turn, cites a list of international accords on religious freedom as its precedents - among them, prominently the European Convention for the Protection of Human Rights and Fundamental Freedoms.
} 
For convenience sake, I shall call this a "market" model, because major Western institutions, like the EU or the US government, like to say, or think, that religions are, or ought to be, "free," in, at least, an analogous sense to that in which liberal economists imagine the market for goods and services is, or should be, "free." But, as we may be learning, religious institutions, like all the institutions of civil society, are neither absolutely, autonomous, free or sovereign - even though they try mightily so to be. Religious institutions depend as much upon political and economic institutions as another. Few churches get built, and thus does the liberty to build them get exercised, as well, across Aleppo-like war-torn landscapes. Even under the normal conditions of life in a nation-state, as long as the state maintains its designated hold on the monopoly of the use of force in a society, it can always coerce any institution to submit to state influence, if not control. Recent radical movements for will-o'-the-wisp church sovereignty in the United States seem to have taken this to heart, in dramatic ways. When Liberty Baptist University opened an on-campus shooting range, it attracted national media attention (Shapiro 2016). So, as well, did the increased activity of an influential Roman Catholic group "ChurchMilitant" (http://www. churchmilitant.com/). But, at the moment, the Eurasian state maintains "sovereignty," not the churches. But even here, as far as the state is concerned, if one means by "state," the "nation-state," we might want to reserve final judgment about the real extent of the sovereignty of today's nation-states until we can better calculate how far globalized interdependence and multi-national corporations compromise their "freedom" or "sovereignty."

Until quite recently, Armenia, with its ancient established church, the Holy Apostolic Armenian Church, (HAAC) was facing the demands of the EU Venice Commission's reforms of its public policy and practice in the area of "religious liberty," so called. Things changed in early September 2013, however, when further negotiations for full association of Armenia with the EU were suspended, in favor of far weaker plans for relations. At that point, the Armenian government may have, perhaps, realized just what the costs of actual association with the EU would be, as spelt out by the Venice Commission, especially in 
light of what could be seen as geopolitically more natural association with Russia's EurAsEC Customs Union. After all, large numbers of otherwise un- or under-employed Armenians worked in Russia. The EurAs EC Customs Union made no demands similar to those required by the Venice Commission's rigorous "religious liberty" requirements. But, although the particular drama of Armenia's approach to the EU may be suspended, the lessons learned in the process of negotiation still apply. To wit, although pluralistic tolerance and "religious liberty" were affirmed in the constitution of the Republic of Armenia, the Venice Commission's report found their official adherence to the letter and spirit of the constitution at odds with its noble aspirations. The Commission claimed that minority churches suffered a range of restrictions, and sometimes even outright harassment. These range from the non-HAAC churches publically being declared "cults" to limitations being placed upon their ability to proselytize, mobilize, or even advertise their existence. Some of the minority churches even complained of incidents threatening their physical well-being. Against this background of intimidation and hostility, the government seemed to favor the HAAC in ways that exceeded its undisputed and well-earned recognition in the formation and preservation of Armenian national identity (Flanagan, et al. 2011). Without my fully being aware of it at the time, Armenia was shaping up as a remarkable case where the battle lines had been drawn - as perplexing as this may sound - between the opposed forces of religious freedom against those of freedom of religion. But, there was more. It also highlighted certain confusing and contrary things about the international religious liberty agenda's campaign for "religious liberty," (whatever that means?) itself.

Nowhere more thoroughly does the Council of Europe reveal what values animate it than the Venice Commission report. This document, and indeed the policies of the Council of Europe as a whole, regarding religious liberty, make liberal values of free choice primary. These values permeate, and are officially inscribed into, Western society in all, if not most, of its domains - including everything from free choice of beliefs, ideas and values to those of association and companionship, as well as to the market place for goods and services. To cite but one 
of many examples that might be mentions, the Venice Commission report states in Paragraph 93, while reiterating the judgments of earlier documents, that "individuals and groups should be free to practice their religion without registration if they so desire - regardless of how small or large their group may be"(Flanagan, et al. 2011). The Venice Commission even singles out the cardinal value of being free to "proselytize" - in effect, to publicize, in effect, offer for sale, adopt or acquire - particular religious association. ${ }^{2}$ In Paragraph 44, the report states that the government

must take into account that any limitation on proselytism or the manifestation of religion, which is a fundamental right, requires careful assessment. There is a thin line between the right to manifest one's religion and change one's beliefs and the right to religious expression, the right to impart and receive even offensive ideas that shock and disturb - yet these are the demands of pluralism, tolerance and broadmindedness without which there is no "democratic society."

Another way to look at this assertion of liberal values in regards to religion is to see them Freakonomically - as the same as the values of the free market. The Venice Commission thus imagines a world shaped by the values of the market, free and rational choice, a venue in which made up of willing buyers and willing sellers. Paragraph 56 accordingly states that "most democratic legal systems do not regulate proselytism per se... Special laws targeting religious persuasion are likely to lead to discrimination and may result in unjust curtailment of legitimate manifestations of religion..." The Council of Europe has, in effect, declared - or at the very least assumes - a world in which there ideally exists what is, in effect, an open, free "market" in religious beliefs.

In such a construction of the values governing religious social reality, they, likewise, assume neutrality among religious beliefs. No religion deserves being privileged save by its ability to attract adherents. And, not even those religions, such as the national churches of the East or the established churches of the West, that may actually be privileged (monopolies) should feel entitled to their privileges. Again, the values

\footnotetext{
${ }^{2}$ See especially paragraphs 42-59.
} 
of there being willing buyers and willing sellers, so to speak, should prevail, not the controlled "market" preferred by the national churches of the East. In Western liberal eyes, to revert again to an economic metaphor, no one is permitted to "have their thumbs on the scale," so to speak, to gain or deserve an advantage over any other buyer or seller. In the eyes of the Venice Commission, all religions ought to expect to compete equally and "fairly" (sic) for adherents. Ideally, the market will not favor any participant, and thus each enters the market as an equal. In the same way candidates for office appeal for votes or, say, automobile, appliance, dry-cleaning, baguette, or computer sales-folk appeal for potential buyers of their goods and services, so also do the religions compete for "consumers." The religions offer their potential "consumers" a commodity - here, religious belief - and the religious marketplace decides how to value it. The Venice Commission thus affirms values common to those of the liberal economic market as those that will govern interaction among religions. Not so, as we will see, in the monopoly-minded East.

\section{When a Free Market of Religions is Not Really Free}

It is not hard to understand why the HAAC seems determined to resist the Venice Commission's open market model of religious relations. Any free market of religions would presume an equally endowed array of willing sellers and willing buyers. But, the HAAC does not believe present-day Armenia fits the model of being an equal player. It has been greatly disadvantaged by the vicissitudes of modern history. Markets need those willing sellers and willing buyers, of which I have already spoken. Even if it did want to compete in a free market, seventy years of systematic Soviet efforts to destroy the HAAC, and all remnants of religion in Armenia have depleted the Apostolic Church's resources of a mature clergy and healthy institutional basis. The Apostolic Church feels that it deserves some consideration for preserving both Armenian nationality and local Christianity through the Soviet period of active oppression of religion. That consideration may well be a permanent monopoly of the religious marketplace for the HAAC. Witness, perhaps to the insensitivity of the arrogant West in appreciating the HAAC's 
weakened condition, she is being asked to compete in a "market" rigged against her - a market that is not really "free." Instead of equally endowed willing buyers and willing sellers, the HAAC faces well-funded and energized religious competitors from abroad.

On the side of the new Protestant missionizing churches, the view differs considerably. These small, sometime struggling communities, such as the Jehovah Witnesses, for instance, see themselves disadvantaged in comparison to the larger and historically more deeply rooted HAAC. To them, it represents a stifling, traditionalist monopoly religion that wants to maintain its hegemony, and restrict the religious choices of Armenians. The Apostolic Church thereby seeks to deny Armenians their religious freedom, their inalienable human right to religious liberty, and thus to free exercise of their religions. It is the past, and they represent the future. From documents like the USA's International RFRA or the EU's Venice Commission report, the West is seen as agreeing with the new missionizing churches.

One example that illustrates what sparked such anxiety for the HAAC in the post-Soviet world was the power of such outside groups like the Church of the Latter-Day Saints (LDS, hereafter). Notable here were the innocent-seeming, indeed generous, philanthropic activities of Jon Huntsman, Sr., father of the GOP presidential candidate, Jon Huntsman, Jr. After the 1988 earthquake in northern Armenia, he capped a 25-year effort of philanthropy in Armenia by funding massive rebuilding projects, founding schools and health care facilities, providing for scholarships for Armenian students to study at Utah State University, and so on. Up against one of the world's richest persons, and a conspicuous adherent to the LDS, it is small wonder that the relatively threadbare HAAC felt outclassed! Reasonable or not, the Apostolic Church sees itself and its position in Armenia threatened by well-meaning, international forces. ${ }^{3}$ The HAAC sees the power of a

\footnotetext{
${ }^{3}$ We need not slight the genuine good Huntsman's resources have done for Armenia. Nor, do we need to slip into an easy cynicism about the ulterior religious motives in Huntsman's gifts. Of course, Huntsman's gift is not "free." As a long-time student of Marcel Mauss, I accept that obligation rules the world of gift giving. All gifts are given under obligation - I must give gifts are also accepted under obligation - I must accept the gift. And, what is more, they are repaid with a force of obligation - I must repay the gift. But, facing the reality
} 
globalized network of religions, mostly based in the US, and funded by American congregations, such as the LDS, as threats to the HAAC's historical monopoly in the religious world of Armenian homeland. And, make no mistake, the term "monopoly" fits the Armenian situation well, even as the HAAC's perfection of that sort of regime has never been complete and has lately been slipping.

\section{Learning from Armenia about Religious Liberty, or Lack of it?}

Assuming liberal or market values when it comes to religion might seem like an obvious and unremarkable place to begin thinking about the engagement of religions in the public square. But, for liberal advocates of religious liberty, Armenia and other nations with state churches, deal out unexpected lessons. Here, polarization rules. Combatants on either side are as entrenched as First World War armies facing each other across the front lines. As far as my visit to Armenia went, doors had been slammed shut even before I had tried to walk in. Unlike the world of a liberal market of religions, presumed by the Venice Commission (and in theory, the Armenian constitution, at least as the EU wished it to become), Armenia represents an entirely different, and hostile territory. It is one thing to think about such matters, but really another one to live through them. What was remarkable was the pre-emptive nature of the collision with those who saw me an opponent from my very first day there. The audiences I was scheduled to address showed promise students at a teachers' college or the American University of Armenia, seminarians of the HAAC, representatives of local NGOs and leaders from local Protestant communities, such as evangelicals, and US affiliated Protestant missionary congregations, such as the LDS - even a national TV audience in prime time. But, no matter how varied these venues, the same entrenched positions stifled serious questioning of any kind from the get-go. These considerations might then be thought a tad theoretical, since the very structure of opposition worked to make

\footnotetext{
of gift giving as interested doesn't condemn us to cynicism. It only forces us to face reality of living in a world of relationships. And, that reality - even Huntsman - can be good, however, motivated, or however not "optimal" from a given point of view.
} 
it even impossible to explore, much less entertain, value options, much less to promote a certain values.

Besides the "schooling" Armenia's polarized religious situation gave me, recent criticisms of the international religious liberty agenda by the likes of Elizabeth Shakman Hurd have also given many of us reason to rethink the entire issue (Hurd 2008; Hurd 2014). Is it always in the best interests of people to assert their right to religious liberty? Are other interests, such as maintaining the social peace of a convivium with other peoples of different religions, more desirable? Would the assertion by one religious group of their religious liberty only provoke endless destructive conflict, and so on? Would not human welfare, Hurd, in effect suggests, be better served by letting thing be - even if this meant inequality, and even monopolies on the religious scene? Armenia provides us with a concrete context in which to consider these and other criticisms of the international religious freedom agenda.

On the one side, how could one not respect the heroic situation of the HAAC, just emerging from Stalinist oppression - a fact to which the Venice Commission report gave scant recognition (Paragraph 43). (And, what form would that take, short of complying with the will of the HAAC in all things religious in Armenia?) And, given the massive majority of those who identified with the HAAC in the country, wasn't it a bit artificial, in effect, to consider it just one of another set of competing religions, all equal in the sight of God and the global market of religions? (But, how could religious liberty for the missionaries be assured short of that?) On the other side, the whole range of (mostly) Protestant evangelicals and the LDS, with their ample funding from abroad, their powerful mass media, their competitive insurgent's energy, were not to be denied. (But, whose country were they seeing operate?) The Protestant missionaries also brought a modern sense openness coupled with a winning desire to do good for Armenia. How and why should this be resisted?

But, maybe, these dilemmas, naturally provoked by the market model, signaled the limit to that model's utility? What is more, this conclusion would be not only apply to Armenia, but to all the nations of the former USSR, including Greece and Turkey - wherever either, 
officially or not, a national religion was in place. In some quarters, the idea of markets in religions may seem uncontroversial, even morally imperative. But, being "on the ground" in Armenia confronts one with the fact of the actual feasibility of the market model. Hegemony, monopoly, or whatever one wants to call them, are real. The Armenian market in religions seemed hopelessly fixed from every angle, certainly from the viewpoint of the HAAC and its local hegemony. But, also it was fixed, or at least unbalanced, from the perspective of the missionary religions, with the material advantages they brought to the market.

While it may be easier to understand the advantages accruing to missionary competitiveness, the ways the HAAC's local position gave it market power are far less obvious. An unwelcome opportunity to discover the subtleties of market manipulation by the HAAC came with visit to the teachers' college at Gyumri. I share it at this point to flesh out the idea of how markets can be manipulated, here, worse than that, how markets can be undermined even before they have had a chance to set up shop. The point is, of course, not to let a potential competitor set up shop at all. That is, in effect, what happened at the state teacher's college in Gyumri.

\section{Subverting the Marketplace of Ideas about Religious Liberty at the Gyumri}

Anyone who wishes to understand the myriad ways states repress religions, and thus restrict religious liberty should consult Ani Sarkissian's, The Varieties of Religious Repression (Sarkissian 2016). She gives us the first relentlessly thorough account of the devices, policies, techniques, strategies and such used by modern nationstates to manipulate religion within their borders. In fact, Sarkissian details so many, that it would be impossible to begin doing her itemization justice. Here, nevertheless are some examples. States may begin by preventing individuals from participating in religious services, or restricting certain groups from participating in religious services, then move on to restricting the location of, or architecture of, places of worship. Not enough, limiting the hours that religious gathering places may be open to the public helps repressive policies, as does coercing conversion, restricting proselytizing directly, or the 
formation of religious communities through discriminatory registration or monitoring requirements. Then, there is always the control over clerical appointments, restricting religious speech, banning religious political parties, and so on and so on (Sarkissian 2016:27ff).

Less noticed by Sarkissian, however, are how attempts to defeat, repress, subvert, or undermine a free market of ideas aid the efforts to undermine a free market in religious liberty. In Gyumri, I discovered that it did so by blocking the application of the methods of modern religious studies - by preventing religion itself from becoming an object of academic or scientific study. At its most elementary, these efforts are aimed at stifling any talk about religion in the public square that purports to be neutral, or disinterested with respect to the doctrinal or other positions under discussion. In effect, this attack upon open discourse is part and parcel of the way repressive states seek to control civil society, in all its diversity. By "neutral," I do not mean some absolute objectivity, disinterestedness, or neutrality, with respect to any and all values, but only a "relative" neutrality - one with respect to dogmatic positions in the contested religious field of inquiry. In a field represented by Catholics and Protestants, an investigator committed to Buddhist, Confucian, Hindu, Jewish or Muslim values might be deemed interested with respect to those values. However, they could claim such prima facie "relative neutrality" with respect to the Protestants and Catholics contestants.

But, in the case I want to illuminate, agents of market manipulation, here, friendly to the HAAC, sought to defeat, undermine, subvert, stifle, and so on, neutral inquiry. They sought to discredit the values of open and disinterested inquiry - here, involving the scientific study of, religion, itself. I have discovered that such a strategy of the repression of inquiry may involve at least three elements. I would be surprised if my list of three broad kinds of techniques of undermining open, disinterested discussion is exhaustive, so readers may want to contribute their own to those I have spelt out here.

The occasion in question was a talk held before a group of about 40 youthful, future teachers at the Gyumri Teachers' College. I prepared for the seminar, ready with a brief, 15-minute PowerPoint presentation - 
really, no more than "fish food" to encourage discussion about religious liberty. I really did not offer my own thinking about how to solve the various conundrums connected to this subject - frankly, because I had no solution to these thorny problems! Instead, I would have been pleased just to listen to and learn about the concerns and opinions of what looked to be a keen group of about 40 young students. As people started taking their seats, I noticed a group of older men, curiously situating themselves, as if by assignment, about the room. When question time began, I soon learned why. Before a single student could speak, however, instead of some light-hearted give and take, those strategically seated older men began peppering me with questions, so much so that they, in effect, monopolized questioning. In Gyumri, they not only turned up in force, arrayed strategically around the room, but they echoed and reinforced each other. Who were they? I thought, perhaps, they were teachers, or mature students, returning for further credentialing. I never really learned who they were, but they succeeded in their purpose. I thought nothing of it at the time, but in retrospect, now I realize what had happened. In effect, I got caught in a carefully concocted ambush conducted that attempted to undermine discussion with provocations, attempts to bait or distract me as a primary discussant, by tempting me to pursue tangential issues. It was obvious that my tormenters were practiced in the art of undermining open discourse by a combination of monopolizing discussion or diverting it.

Second, silencing discussion. The antics of these older men succeeded in effectively silencing other members of the assembly from effectively speaking. Students seemed to recognize them for what they were, and feared them. Their mere presence effectively intimidated the others in the assembly into silence. In Gyumri, the students took note. They knew who they were, even though I did not. They had seen this movie before, and kept their heads down.

Third, entrapment. Finally, and subtlest of all, these agents of repression might try to trap a speaker into veering from neutrality. They might do this by challenging a speaker to declare their "where they stand," typically by challenging the candor of a speaker for withholding their own commitments. But, were one to surrender and accept being 
the bearer of a "message," a speaker would lose their credentials as an honest broker, as neutral, in a given discussion. In Armenia, for instance, I truly wanted to orient myself to the local situation by scrupulously seeking to listen to all sides in the dispute over religious liberty. At one point, apparently exasperated by my passive stance, I was asked by one of the agents of repression, "But what is your message?" I was briefly stunned, since delivery a message was really far from my mind. If I had a hidden agenda, which I ironically did not have, it would have been that I had no agenda, no message! But, despite lacking a message, when asked such a question, I do admit having felt tempted to retort with a reply as requested. Yet, had I done so, rather than stammer, as I did, something about not having a message, I would have trapped myself into being seen as just another dogmatist, just another messenger. I would have been tricked into defeating my own purposes of seeking open, disinterested, neutral discussion. In Armenia, agents of repression were ready with an ample armory of weapons ready to defeat serious engagement in questions about religious liberty by first undercutting the possibility of discussing religion at all in neutral, or non-dogmatic, ways. I was truly thus caught in a verbal "ambush." But, though I may have been left for dead, I was far from it.

\section{If Not Markets, What?}

In Gyumri, then, I experienced, first-hand, how a marketplace of religious can be frustrated from forming at all. A symptom of Armenia's religious polarization, it, nonetheless, did offer food for thought. One way I had thought to tease out some views was in fact, objectively and frankly, to present an alternative model to the religious liberty market model. For starters, one might try to recognize the concerns of the HAAC, and argue that we should query the idea of a truly free-for-all, open market, where religions duked it out against one another. This was nothing but an attempt to provoke a discussion of how we could we better conceive the relationship between the HAAC and both the new Protestant missionary churches? The same goes as well for the local, resident Protestant (also some Roman Catholic and Orthodox) churches of relative longstanding? 
What model would enshrine the values that would best prescribe how these communities should look on each other?

First, just to shake up things a bit, a little thought adventure. When situations seem so dire, we tend to focus more and more on the details of our immediate slice of history, here, in Armenia in the 21st century. But, why not reset our perspective first and assume a grander purview? Imagine a vantage point 50,000 feet above Armenia and 50,00 years into the past. From there, Armenia, much like Israel/Palestine, sits squarely on a land bridge between larger continental masses. Human migrations out of Africa had traipsed across this "Armenia" for tens of thousands of years. Contrary to the way, Armenians may feel in Fortress Armenia, the space occupied by today's Armenia has always swarmed with peoples on the move. Understandably, both the trauma of the genocide and its newly acquired independence has made Armenians more conscious of their vulnerability, finitude and isolation. But, especially when we add the stunning reality of the Armenian diaspora to my imaginative reflection on Armenia's place in the prehistoric movement of peoples, the present fixation upon the present-day Republic of Armenia might begin to seem disproportionate. If the ancient history of Armenia challenges beliefs about Armenian uniqueness and insulation from the flows of history, what does it mean to Armenian self-consciousness that three times the number of Armenians live in the diaspora than in the Republic - 10 million there, and only 3.5 million in Armenia, proper.

Let me suggest that these historic and demographic facts might offer reasons to reconsider the stalemate endgame that the market vs. monopoly model of religious relationship in Armenia has produced? I find it hard to believe that the only way to think about religions in relation is either as competing commodities in an ideal-type market or as alienated subjects of a religious monopoly. This is not to say that another model, such as I shall now suggest, will be flawless, or indeed that any model for thinking about this matter will be. But, what harm can come from entertaining different ways of conceiving situation especially those that seem at loggerheads? 


\section{The Values of Being Good Hosts and Guests}

Accordingly, to challenge the ubiquitous model of market vs. monopoly values, one might consider another possible alternative model of values regulating religious interaction - the values of being good hosts/guests. In particular, as I shall now elaborate, one might regard the non-HAAC churches seeking access to Armenia as potential "guests." If such a substitution sounds softheaded or sentimental, or both, I would strongly object. Indeed, the guest/host model has particularly apt application to Armenia. Consider the particularity of Armenia's wellknown and often celebrated diaspora communities. Armenians have been welcome "guests" the whole world over, however, familiar, even if painfully so, this may be. Were I an Armenian, I would be distinctly proud that Armenian "guests" (i.e., migrants) have a history of being so welcomed in so many different parts of the world. (I, of course, exclude the Genocide.) Today Armenians are, in effect, one of the world's more prominent and successfully integrated "guest" communities. Indeed, the vitality, growth, deployment and success of the international Armenian migrant diaspora ought to be recognized as a great success story of international social integration. But, the very success of the diaspora, the very warmth of the welcome accorded Armenians in diaspora, puts Armenia in debt to the world. Is not something owed in return? Thus, far from being soft and sentimental, proposing this guest/ host model recognizes the reciprocal debt Armenia has incurred to be a host nation itself.

In Armenia, complaints of suppression by Protestant missionary groups have, in effect, made religious liberty an issue in Armenia. They feel aggrieved by feeling frozen out of the Armenian marketplace of religions by the monopoly power of the HAAC. They claim that the HAAC or its agents have sought to restrict their ability to "sell" their version of religion in the Armenian marketplace. Put in the alternative mode that I am proposing, why would not we say as well that the HAAC does not wish to "host" the Protestant missionaries, it does not want to extend to them the honor of being "guests" in Armenia. (I need to say immediately, however, that several of the non-HAAC churches 
are well-established in Armenia, and not "new" in the sense that the post-1989 mission churches are, and hence do not exactly qualify a "guests." The Armenian Evangelical Church, for example, dates from 1846 in Armenia. Small numbers of Roman Catholics and Russian Orthodox, but notably evangelicals (1\%) balance to over $92 \%$ who claim allegiance to the AAC) Might, then, this alternative perspective of religious contact as conforming more to the host/guest model than the liberal market model, at least, make us stop and think, even if we rushed back to our old positions thereafter?

I have no solution for this puzzle, but cannot help but perhaps elaborating it according to the guest/host model may induce some fresh thinking. I have already said why it might be argued that Armenians find themselves in an awkward position with respect to others, wishing to come to Armenia, since their own kind have been so welcomed abroad. How would one counter the argument that the very existence of such a large diaspora - about 4 times the population of Armenia proper - may place a moral burden upon Armenians to be good "hosts" of these new stranger religions? Next, of course, a lack of hospitality towards the new missionary groups could be said to offend longstanding cultural norms. A glance at Armenia's location on the Caucasian land bridge between the Middle East and northeastern Europe and central Asia, and its 50,000 year history as a conduit for migrant human populations for bespeak a people who have learned how to engage the stranger. Despite its present-day look of isolation, Armenia has always been a crossroads of world's populations. Does any of this suggest new policies towards the new "visitors"?

Up to this point, I have been showing how the values expressed in the guest/host model of relations suggest other modes of behavior that the HAAC "hosts" might have otherwise not considered. But thinking about the relation of say, the new missionaries and the HAAC, cuts both ways. Replacing the market model with the host/guest model has value implications the new Protestant missionaries. A "guest" is not the same as a "consumer" or "salesperson." If the Protestant missionaries think of themselves more as guests than as salespeople do, I believe they would have to entertain different sorts of values in regulating their 
behavior. A "guest" in Armenia, say, should conceive of themselves, first, as having been given the gift of, at least, provisional acceptance. Guests, unlike, salespeople or consumers, are not free of the logic of gift and obligation. The entire point of replacing gift with commodity is precisely to eliminate moral considerations. Caveat emptor. As a guest, however, one would be expected to behave as if one were welcomed into the Armenian "house," so to speak. As such, guests are expected to restrain themselves in certain ways, even as they enjoy corresponding privileges. The best silverware is put out for the guest, but correspondingly, the guest is trusted not to run off with the silverware, as it were! Or, guests are expected to educate themselves about their hosts, so that they can, again, behave accordingly. For instance, it would seem to be both seemly good manners and decent historical awareness that the new missionary religions in Armenia recognize what the HAAC is and has been. One might, also, frankly admit the oddity of Christians seeking to missionize the first officially Christian nation! Why would not that be a little like a case of "bringing coals to Newcastle"? Further, putting such encounters into a broader and deeper historical context, we might all be reminded of the ignorant disrespect Latin Christians have meted out to Eastern Christians over a very long history, whether in Protestant or Roman Catholic form.

For these reasons alone, more systematic acknowledgment, respect and admiration on the part of Latin Christians for their poorer Eastern cousins might be in order. I am not sure what form that should take, or what will, should or could happen once it did. Perhaps host/ guest reciprocity could if those foreign, American, say, missionary groups took the lead in receiving Armenian immigrants into their new homes in the Diaspora? Are the foreign Christian missionaries being good 'Christians' at home by offering real hospitality to Armenian migrants to the United States? Doing so might start a "virtuous cycle" of guest/host reciprocity, perhaps even educating would-be Protestant Christian missionary churches about the place of HAAC in the history of Christianity? But, until the sometimes-perceived zeal of the new foreign missionaries is tempered by some humility for the historic communities of Eastern Christianity, the new missionaries risk being 
seen as barbarians who offend all the ancient and sacred rules of hospitality. Without the realization of a theology of mutual respect and recognition, both sides will continue to be estranged from each other. That is work for theologians on all sides of this issue.

The challenge remains great for those who want to foster open discussions of central values about the optimal relation of religions in post-Soviet states, like Armenia, with its historic national churches. Perhaps, too much is invested in the outcomes of such discussions for principal participants? As a result, really open conversation about key values becomes difficult, whether by nature or by deliberate resistance. I can say this with some authority, because not only my Gyumri conference and talk systematically subverted, but also immediately thereafter the HAAC authorities canceled my much-anticipated meeting with their seminarians. Whether this was in anticipation of my merely trotting out the familiar position of the US religious liberty agenda or not, I shall never know. But, if the HAAC seminary authorities felt every visitor was going to "sing" from the RFRA (the Religious Freedom Restoration Act), IRFA (International Religious Freedom Act) and the Venice Commission report's "hymnals," they could easily have justified the cancelation to themselves. "Who are these people to preach to, the HAAC, about religion in our own country?!" What need Armenia for a new batch of Christian missionaries, when it was already a nation of Christians, indeed an officially Christian nation - the first - since 303 CE? But, other visitors might have loved to have had a chance to listen and learn from them about their perspective on the entire religious liberty question.

Ironically, the authorities often do not realize that even visiting American academics could have deep sympathies for their doubts about the Western, neo-liberal, market model of religions proposed for Armenia by the EU and the US. For instance, the often-triumphal arrogance of today's reformed Latin Christians rehearses the historic disrespect for Coptic and Orthodox Christianity that Saba Mahmood so well explored recently. (Danchin, et al. 2015) Such deep-seated or deeply designed suspicions, alas, can successfully prevent reaching some level of mutual recognition and respect. So, leaders of the 
historic Eastern churches might want at least to listen to what the next roving academic has to say. Some of us academics value openness. We seek to learn from others by listening by virtue of the very vocation we have chosen to pursue. Some Western academics do respect the historic churches of the East, as much as they feel sympathy for the sometimes struggling, sometimes well-financed missionaries from the West. I have tried to argue here that both sides might better exploit the situation of contact and exchange by seeing each other as hosts and guests, rather than as buyer and sellers of religion.

\section{References}

Danchin, P. G. Sullivan, W. F., Hurd, E. S. \& Mahmood, S. (Eds.). (2015). Politics of Religious Freedom. Chicago: University of Chicago Press.

Fanagan, F., Thoreirsdottir, H. \& OSCE/ODIHR Advisory Council on Freedom of Religion and Belief (2011). Joint Opinion on the Draft Law on Freedoms of Conscience and Religion and of the Laws Making Amendments and Supplements to the Criminal Code, the Administrative Offences Code and the Law on the Relations between the Republic of Armenia and the Holy Armenian Apostolic Church of the Republic of Armenia. In European Commission for Democracy through Law (Venice Commission). T.V.C.a.t. OSCE/ODHIR, ed. Pp. 22, Vol. CDLAD (2011) 028. Strasbourg: Council of Europe.

Hurd, E. S. (2008). The Politics of Secularism in International Relations. Princeton: Princeton University Press.

Hurd, E. S. (2014) International "Religious Freedom" Agenda Will Only Ebolden iSiS. In Religion Dispatches. Los Angeles: USC Annenburg School of Journalism. Retrieved from http://religiondispatches.org/ international-religious-freedom-agenda-will-only-embolden-isis/

Levitt, S. D., and Dubner, S. J. (2009). Freakonomics: A Rogue Economist Explores the Hidden Side of Everything. New York: Wiliam Morrow.

Polanyi, K. (1944). The Great Transformation. New York City: Farrar and Rinehart. 
Sarkissian, A. (2016). The Varieties of Religious Repression. New York: Oxford University Press.

Shapiro, T. R. (2016) Gun-friendly Liberty University to Open OnCampus Shooting Range. In The Washington Post, December 15.

Retrieved from https://www.washingtonpost.com/news/gradepoint/wp/2016/12/15/gun-friendly-liberty-university-to-open-oncampus-shooting-range/?utm term=.ae1914644d9a 